however, revealed wide differences in the relative activities of the two pathways in comparable tissues of different species.

We wish to thank Professor John Lind, Department of Pediatrics, Karolinska Hospital, and Professor Carl Schmitterlow, Department of Pharmacology, Kungl. Veterinärhögskolan, for their generosity in providing the foetal specimens and the laboratory facilities for the experiments in Stockholm. This work was aided by grants from the Charles and Marjorie King Fund, from the Association for the Aid of Crippled Children, and Grant C-2400 from the National Institutes of Health.

\section{REFERENCES}

Barker, S. B. \& Summerson, W. H. (1941). J. biol. Chem. 138, 535.

Brown, A. K., Zuelzer, W. W. \& Bollet, A. J. (1958). A.M.A. Amer. J. Dis. Child. 96, 487.

de Duve, C. \& Hers, H. G. (1957). Annu. Rev. Biochem. 26, 149.

Field, J. B., Pastan, I., Herring, B. \& Johnson, P. (1960). Endocrinology, 67, 801.
Folch, J., Lees, M. \& Sloane-Stanley, G. H. (1957). J. biol. Chem. 226, 497.

Glock, G. E. \& McLean, P. (1955). Biochem. J. 61, 388.

Katz, J. \& Wood, H. G. (1960). J. biol. Chem. 235, 2165.

Krahl, M. E. (1956). Biochim. biophys. Acta, 20, 27.

Kretchmer, N. (1959). Pediatrics, Springfield, 23, 606.

Lathe, G. H. (1959). Trans. 3rd Josiah Macy, jun., Conf., Physiology of Prematurity.

Nelson, N. (1944). J. biol. Chem. 153, 375.

Siperstein, M. D. (1958). Diabetes, 7, 181.

Villee, C. A. (1953). J. biol. Chem. 205, 113.

Villee, C. A., Hagerman, D. D., Holmberg, N., Lind, J. \& Villee, D. B. (1958). Pediatrics, Springfield, 22, 953.

Villee, C. A., Loring. J. \& Wellington, F. (1957). Biol. Bull., Wood's Hole, 113, 358.

Villee, D. B., Engel, L. L., Loring, J. M. \& Villee, C. A. (1961). Endocrinology, 69, 354.

Villee, D. B., Engel, L. L. \& Villee, C. A. (1959). Endocrinology, 65, 465.

Walaas, O. \& Walaas, E. (1950). J. biol. Chem. 187, 769.

Wick, A. N., Drury, D. R., Nakader, H. I. \& Wolfe, J. B. (1957). J. biol. Chem. 224, 963.

Biochem. J. (1961) 81, 494

\title{
A Study of the Gitric Acid Cycle in Certain Tumour Tissues
}

\author{
By R. M. DAJANI, JOYCE DANIELSKI, W. GAMBLE AND J. M. ORTEN \\ Department of Physiological Chemistry, Wayne State University College of Medicine, \\ Detroit, Michigan, U.S.A.
}

(Received 13 February 1961)

At present there are two schools of thought about the respiration of cancer cells. Whereas both agree that tumour tissues exhibit high anaerobic and aerobic glycolysis with an excessive production of lactic acid (Cori \& Cori, 1925; Warburg, 1926, 1956), they differ as to the extent of the operation of the citric acid cycle in these tissues (Weinhouse, 1955; Weinhouse, Warburg \& Burk, 1956; Warburg, 1956). In these studies the activity of certain segments of the cycle has been determined by oxygen consumption and carbon dioxide production procedures (Warburg, 1926; Busch \& Potter, 1952; Busch \& Baltrush, 1954; Busch, 1955; Weinhouse, 1955; Warburg, 1956; Ibsen, Coe \& McKee, 1958), by measuring the glycolytic and oxidative enzymes (Sibley \& Lehninger, 1949; LePage, 1950; Meister, 1950; Potter, 1951; Weinhouse, 1951; Wenner, Spirtes \& Weinhouse, 1952; Beck, 1958), and the cofactors of the electron-transport system (Dubois \& Potter, 1942; Wenner \& Weinhouse, 1953; Greenstein, Werne, Eschenbrenner \& Leuthardt,
1944), or by following the utilization of the various intermediates of the Embden-Meyerhof scheme and the tricarboxylic acid cycle (Pardee \& Potter, 1949; Elliott \& Kalnitsky, 1950; Olson, 1951; Wenner \& Weinhouse, 1952; Heidelberger, 1953; Busch \& Baltrush, 1954). However, none of these investigators has utilized the simultaneous determination of the amounts and radioactivities of all the members of the citric acid cycle in vitro in the presence and absence of certain added labelled substrates and blocking agents. Such a procedure could reflect the activity of the cycle if an excess of substrate is present despite the fact that the individual cycle acids allegedly serve a 'catalytic' function. There are examples of variations in the amounts of the individual cycle acids under differing experimental conditions, for example, after the addition of specific blocking agents. The present study was designed to employ such a direct approach. The tumour and normal tissue preparations were incubated with $\left[{ }^{14} \mathrm{C}\right]$ acetate, 
$\left[{ }^{14} \mathrm{C}\right]$ succinate or non-labelled malate and the amounts and activities of the individual cycle acids were determined as described by Dajani \& Orten (1958). The results conclusively demonstrated a quantitatively reduced activity of the tricarboxylic acid cycle in the tumours as compared with the normal tissues studied under the conditions of the experiments.

\section{EXPERIMENTAL}

\section{Materials}

DPN, ATP, succinic acid and L-malic acid, all purified grade, were purchased from the California Foundation for Biochemical Research, Los Angeles, Calif. [1-14C]Acetate and $\left[1{ }^{14} \mathrm{C}\right]$ succinate were obtained from Volk Radiochemical Co., Chicago, Ill. Penicillin G potassium was a product of Lederle Laboratories, New York; the dihydrostreptomycin was produced by Pfizer and Co., New York. Triethyltin acetate was kindly supplied by $\mathrm{Dr}$ K. E. Moore, University of Michigan, and by the Metal and Thermite Corp., New York City.

Three types of tumour tissues were used: Ehrlich mouseascites-tumour cells, and Walker and LC-18 carcinoma from adult rats. The Walker carcinoma was originally a human adenocarcinoma of the adrenals and the LC-18 carcinoma was originally a human hepatoma. Both had undergone repeated transfers in Fisher strain white rats and were implanted and grown subcutaneously. The normal tissues used for comparison were muscle, liver and isolated liver cells from Fisher strain adult rats and nucleated erythrocytes from Plymouth Rock chickens.

\section{Procedure}

Twenty per cent homogenates of pooled tumour and non-tumour tissues from 8-10 rats were prepared at $5^{\circ}$ in $50 \mathrm{ml}$. of Krebs-Ringer phosphate buffer (pH 7.4) with the use of a Potter-Elvehjem glass homogenizer. To the homogenates were added the following substances, together with the various substrates used, dissolved in $5 \mathrm{ml}$. of Krebs-Ringer phosphate: L-malic acid, $0.05 \mathrm{mg}$.; ATP, $8.0 \mathrm{mg}$.; DPN, 2.0 mg.; monofluoroacetic acid (where used), $0.5 \mathrm{mg}$; ; sodium malonate (where used), $75.0 \mathrm{mg}$; penicillin, 1-2 mg.; streptomycin, 2-4 mg. Sodium fluoride $(0.01 \mathrm{M}$ final concentration) was added to the Krebs-Ringer phosphate used in homogenization in order to prevent loss of ATP and DPN by adenosine triphosphatase and diphosphopyridine nucleotidase (NAD nucleosidase) respectively. In an additional series of experiments triethyltin acetate, a recently introduced powerful and complete adenosine-triphosphatase inhibitor(Dr K. E. Moore, personal communication), was added to the fluid mixture used in the homogenization of tissues in the recommended final concentration $(1 \mu \mathrm{M})$. The supplementary DPN, ATP, as well as triethyltin acetate, were added as a further precautionary measure because there is some evidence that homogenized tissues, particularly certain tumours, exhibit increased activity of adenosine triphosphatase and probably diphosphopyridine nucleotidase. The amounts of the substrates used are given as subheadings to the appropriate Tables. The addition of these substrates to the tissue preparations followed the pro- cedure described elsewhere (Dajani \& Orten, 1958). The mixtures were incubated at $37-38^{\circ}$ in $\mathrm{O}_{2}+\mathrm{CO}_{2}(95: 5)$ for $30 \mathrm{~min}$. and $1,4,18$ or $24 \mathrm{hr}$, with constant gentle shaking (250 oscillations/min.). Since incubation for the shorter intervals did not result in an accumulation of the cycle acids to significantly measurable quantities in the presence of inhibitors, the $4 \mathrm{hr}$. time interval was chosen for incubation in all subsequent experiments. Although a longer period, $18 \mathrm{hr}$., gave higher values, the picture obtained was similar and the shorter period was adopted. In all of these trial studies excess of substrate was always detected at the end of the experiment. However, after incubation for $24 \mathrm{hr}$. no substrate remained, and the levels of the cycle acids were diminished. It should be emphasized at this point that all the experimental conditions adopted were also found to support vigorous Krebs-cycle activity in nucleated erythrocytes (Dajani \& Orten, 1958). As a further check, the $\mathrm{pH}$ of the mixtures was determined at the end of the $4 \mathrm{hr}$. period. No significant change had occurred. At the end of the incubation period, the enzymic reactions were stopped by freezing, and the extraction and determination of the citric acid-cycle acids and their ${ }^{14} \mathrm{C}$ activities followed the procedure that has already been reported (Dajani \& Orten, 1958). The citric acid-cycle acids were extracted with acid-acetone and the amounts and ${ }^{14} \mathrm{C}$-activities of the individual cycle acids were quantitatively determined after separation by silica-gel-column chromatography by a procedure developed in this Laboratory and described in detail by Dajani \& Orten (1958). Essentially the procedure involved the differential elution of the cycle acids from the silica-gel column by automatically increasing concentrations of tert.-amyl alcohol in chloroform. The eluted acids were collected in an automatic fraction collector and then titrated with standard sodium hydroxide by using a Rehburg microburette. The titrated fractions were then transferred to planchets, evaporated to dryness and the ${ }^{14} \mathrm{C}$-activities determined in a gas-flow counter. The flow of effluent through the chromatographic column was slowed by the excessive amounts of lipid in the extracts of tumour tissue, resulting in a poor separation of the cycle acids, so the procedure was modified to remove lipid. For this purpose, the aqueous concentrate of the acid-acetone extract was shaken in a separating funnel with ether $(10 \mathrm{ml}$.). After $15 \mathrm{~min}$., the ether layer was transferred to aluminum planchets and evaporated to dryness, and the radioactivity was determined. The aqueous layer was used for determination of the cycle acids (Dajani \& Orten, 1958). No significant loss of cycle acids by this treatment was found in recovery studies.

Preparation of cell suspensions. Ehrlich mouse-ascitescarcinoma fluid containing the tumour cells was aspirated from the peritoneal cavity of 20-25 ether-anaesthetized mice. The fluid was pooled and the free cells were obtained by differential centrifuging at $200 \mathrm{~g}$ for $5 \mathrm{~min}$. and then at $3000 \mathrm{~g}$ for $15 \mathrm{~min}$. The cells were washed twice with KrebsRinger phosphate and suspended in $50 \mathrm{ml}$. of KrebsRinger phosphate (pH 7.4), or Krebs-Ringer phosphate containing $20 \%$ of clear ascites fluid, to make a $20 \%$ cell suspension. Hepatic cells from normal rats were isolated by the procedure of Branster \& Morton (1957). Nucleated erythrocytes were prepared as described by Dajani \& Orten (1958). These cells were suspended in $50 \mathrm{ml}$. of Krebs-Ringer phosphate, to give a $20 \%$ suspension. The rest of the procedure was the same as that given above. 


\section{RESULTS}

Experiments represented in Tables 1 and 2 on normal and tumour tissues permit a comparison of the utilization of $\left[1-{ }^{14} \mathrm{C}\right]$ acetate by way of the Krebs cycle in these tissues. The amounts of acids listed in these and subsequent Tables are increases over controls (no substrate added). It is evident that the concentrations and ${ }^{14} \mathrm{C}$-activities of the citric acid-cycle intermediates are lower in the tumour tissues than in normal liver or muscle. Also, there is more incorporation of ${ }^{14} \mathrm{C}$ into the cycle acids in LC-18 carcinoma tissue than in Walker carcinoma.
In the studies represented in Tables 1 and 2, it may be recalled that fluoride was added to the homogenates of the tissues to inhibit adenosine triphosphatase and diphosphopyridine nucleotidase. Since it appears possible that fluoride may not have completely inhibited these phosphatases when present at the elevated levels claimed in tumour tissues, triethyltin acetate was employed as an adenosine-triphosphatase inhibitor in place of fluoride. The results, given in Table 3, confirm those found when fluoride was used and thus indicate that the lower activity of the cycle, in LC-18 tumour tissues at least, is not due to a loss or destruction of ATP.

Table 1. Average concentrations ( $\mu$ moles/100 g.) of Krebs-cycle acids in tissues incubated with $\left[1-{ }^{14} \mathrm{C}\right]$ acetate

Values are net syntheses above controls and are averages of three experiments \pm average deviations, with different batches of pooled tissues. The substrate contained: $0.45 \mathrm{mg}$. of [1-14 C]acetate (4.11 mc/m-mole); $4.0 \mathrm{mg}$. of sodium acetate trihydrate. These were dissolved in the incubation mixture, which contained in each $50 \mathrm{ml}$. of Krebs-Ringer phosphate buffer (pH 7.4): L-malic acid, $0.05 \mathrm{mg}$.; ATP, 8.0 mg.; DPN, 2.0 mg.; NaF, $21.0 \mathrm{mg}$.; penicillin, $2 \mathrm{mg}$; dihydrostreptomycin, $4 \mathrm{mg}$.; monofluoroacetic acid (where used), $0.5 \mathrm{mg}$. No substrate was added to the controls.

\begin{tabular}{|c|c|c|c|c|c|c|}
\hline Acid & Control & $\begin{array}{l}\text { Acetate } \\
\text { Liver }\end{array}$ & $\begin{array}{l}\text { Acetate }+ \\
\text { fluoroacetate }\end{array}$ & Control & $\begin{array}{l}\text { Acetate } \\
\text { Muscle }\end{array}$ & $\begin{array}{c}\text { Acetate }+ \\
\text { fluoroacetate }\end{array}$ \\
\hline \multirow[t]{2}{*}{$\begin{array}{l}\text { Citric } \\
\text { Aconitic }(c i s+\text { trans }) \\
\text { isoCitric } \\
\alpha \text {-Oxoglutaric } \\
\text { Succinic } \\
\text { Fumaric } \\
\text { L-Malic } \\
\text { Oxaloacetic + acetoacetic }\end{array}$} & $\begin{array}{l}1 \cdot 1 \pm 0 \cdot 02 \\
0 \cdot 4 \pm 0 \cdot 01 \\
0.5 \pm 0 \cdot 01 \\
1 \cdot 3 \pm 0 \cdot 03 \\
1 \cdot 7 \pm 0 \cdot 07 \\
1 \cdot 5 \pm 0 \cdot 06 \\
1 \cdot 3 \pm 0 \cdot 03 \\
0 \cdot 2 \pm 0.01\end{array}$ & $\begin{array}{l}3 \cdot 0 \pm 0 \cdot 06 \\
0 \cdot 6 \pm 0 \cdot 02 \\
0 \cdot 6 \pm 0 \cdot 01 \\
3 \cdot 8 \pm 0 \cdot 08 \\
4 \cdot 4 \pm 0 \cdot 07 \\
3 \cdot 8 \pm 0 \cdot 05 \\
3 \cdot 5 \pm 0 \cdot 06 \\
1 \cdot 0 \pm 0 \cdot 02\end{array}$ & $\begin{array}{l}2 \cdot 0 \pm 0 \cdot 02 \\
0 \cdot 9 \pm 0 \cdot 01 \\
0 \cdot 8 \pm 0 \cdot 01 \\
2 \cdot 2 \pm 0 \cdot 02 \\
3 \cdot 8 \pm 0 \cdot 06 \\
3 \cdot 6 \pm 0 \cdot 05 \\
3 \cdot 3 \pm 0 \cdot 03 \\
6 \cdot 2 \pm 0 \cdot 07\end{array}$ & $\begin{array}{l}1 \cdot 0 \pm 0 \cdot 01 \\
0 \cdot 3 \pm 0 \cdot 01 \\
0 \cdot 4 \pm 0 \cdot 02 \\
0 \cdot 9 \pm 0 \cdot 01 \\
1 \cdot 5 \pm 0 \cdot 03 \\
1 \cdot 4 \pm 0 \cdot 02 \\
1 \cdot 3 \pm 0 \cdot 04 \\
0 \cdot 3 \pm 0 \cdot 01\end{array}$ & $\begin{array}{l}3 \cdot 3 \pm 0 \cdot 03 \\
0 \cdot 5 \pm 0 \cdot 01 \\
0 \cdot 7 \pm 0 \cdot 02 \\
2 \cdot 4 \pm 0 \cdot 06 \\
4 \cdot 2 \pm 0 \cdot 07 \\
3 \cdot 9 \pm 0 \cdot 05 \\
3 \cdot 6 \pm 0 \cdot 05 \\
0 \cdot 8 \pm 0 \cdot 02\end{array}$ & $\begin{array}{l}4 \cdot 6 \pm 0 \cdot 08 \\
0 \cdot 8 \pm 0 \cdot 02 \\
0 \cdot 8 \pm 0 \cdot 01 \\
2 \cdot 1 \pm 0 \cdot 02 \\
3 \cdot 9 \pm 0 \cdot 06 \\
3 \cdot 7 \pm 0 \cdot 08 \\
3 \cdot 5 \pm 0 \cdot 07 \\
5 \cdot 9 \pm 0 \cdot 05\end{array}$ \\
\hline & \multicolumn{3}{|c|}{ Walker carcinoma } & \multicolumn{3}{|c|}{ LC-18 carcinoma } \\
\hline $\begin{array}{l}\text { Citric } \\
\text { Aconitic }(c i s+\text { trans }) \\
\text { isoCitric } \\
\alpha \text {-Oxoglutaric } \\
\text { Succinic } \\
\text { Fumaric } \\
\text { L-Malic } \\
\text { Oxaloacetic + acetoacetic }\end{array}$ & $\begin{array}{l}0 \cdot 5 \pm 0 \cdot 01 \\
0 \cdot 2 \pm 0 \cdot 03 \\
0 \cdot 3 \pm 0 \cdot 03 \\
0 \cdot 4 \pm 0 \cdot 03 \\
0 \cdot 2 \pm 0 \cdot 01 \\
0 \cdot 3 \pm 0 \cdot 04 \\
0 \cdot 3 \pm 0 \cdot 03 \\
0 \cdot 4 \pm 0.02\end{array}$ & $\begin{array}{l}0.7 \pm 0.02 \\
0.5 \pm 0.04 \\
0.5 \pm 0.03 \\
1.5 \pm 0.06 \\
1 \cdot 4 \pm 0.04 \\
1 \cdot 4 \pm 0.03 \\
1 \cdot 4 \pm 0.02 \\
1 \cdot 3 \pm 0.02\end{array}$ & $\begin{array}{l}1 \cdot 5 \pm 0 \cdot 03 \\
0.9 \pm 0.02 \\
0 \cdot 9 \pm 0 \cdot 01 \\
1 \cdot 4 \pm 0 \cdot 06 \\
1 \cdot 0 \pm 0.04 \\
1 \cdot 0 \pm 0 \cdot 03 \\
0.9 \pm 0 \cdot 04 \\
2 \cdot 9 \pm 0.06\end{array}$ & $\begin{array}{l}0 \cdot 5 \pm 0 \cdot 07 \\
0 \cdot 3 \pm 0 \cdot 02 \\
0 \cdot 3 \pm 0 \cdot 04 \\
0 \cdot 3 \pm 0 \cdot 03 \\
0 \cdot 6 \pm 0 \cdot 02 \\
1 \cdot 5 \pm 0 \cdot 06 \\
0 \cdot 4 \pm 0 \cdot 04 \\
0 \cdot 3 \pm 0 \cdot 03\end{array}$ & $\begin{array}{l}0 \cdot 6 \pm 0 \cdot 03 \\
0 \cdot 5 \pm 0.04 \\
0 \cdot 6 \pm 0 \cdot 02 \\
1 \cdot 7 \pm 0 \cdot 03 \\
2 \cdot 1 \pm 0.05 \\
2 \cdot 4 \pm 0 \cdot 05 \\
1 \cdot 2 \pm 0 \cdot 04 \\
1 \cdot 3 \pm 0.03\end{array}$ & $\begin{array}{l}1 \cdot 7 \pm 0.06 \\
1 \cdot 1 \pm 0.03 \\
1 \cdot 1 \pm 0.01 \\
1 \cdot 5 \pm 0.03 \\
1 \cdot 8 \pm 0.08 \\
1 \cdot 9 \pm 0.07 \\
1 \cdot 2 \pm 0.04 \\
3 \cdot 8 \pm 0.08\end{array}$ \\
\hline
\end{tabular}

Table 2. Average ${ }^{14} \mathrm{C}$ counts $\left(10^{-8} \times\right.$ counts $/$ min. $/ 100$ g. $)$ of Krebs-cycle acids in tissues incubated with $\left[1-{ }^{14} \mathrm{C}\right]$ acetate

Values are averages of three experiments, with different batches of pooled tissues. The substrate and composition of the incubation mixture are given in Table 1.

\begin{tabular}{|c|c|c|c|c|c|c|c|c|}
\hline \multirow[b]{2}{*}{ Acid } & \multicolumn{2}{|c|}{ Liver } & \multicolumn{2}{|c|}{ Muscle } & \multicolumn{2}{|c|}{ Walker carcinoma } & \multicolumn{2}{|c|}{ LC-18 carcinoma } \\
\hline & Acetate & $\begin{array}{c}\text { Acetate + } \\
\text { fluoro- } \\
\text { acetate }\end{array}$ & Acetate & $\begin{array}{c}\text { Acetate }+ \\
\text { fluoro- } \\
\text { acetate }\end{array}$ & Acetate & $\begin{array}{c}\text { Acetate }+ \\
\text { fluoro- } \\
\text { acetate }\end{array}$ & Acetate & $\begin{array}{c}\text { Acetate }+ \\
\text { fluoro- } \\
\text { acetate }\end{array}$ \\
\hline Citric & $110 \cdot 0$ & $105 \cdot 0$ & $125 \cdot 0$ & $203 \cdot 0$ & $7 \cdot 4$ & $8 \cdot 7$ & $7 \cdot 9$ & $9 \cdot 5$ \\
\hline Aconitic (cis + trans) & $\mathbf{3 0 \cdot 0}$ & $\mathbf{3 1} \cdot \mathbf{0}$ & $\mathbf{3 8} \cdot 0$ & $\mathbf{3 0 \cdot 0}$ & $3 \cdot 2$ & $2 \cdot 7$ & $3 \cdot 4$ & $2 \cdot 8$ \\
\hline isoCitric & $38 \cdot 0$ & $32 \cdot 0$ & $36 \cdot 0$ & $\mathbf{3 4} \cdot \mathbf{0}$ & $3 \cdot 2$ & $2 \cdot 6$ & $3 \cdot 3$ & $2 \cdot 7$ \\
\hline$\alpha$-Oxoglutaric & $95 \cdot 0$ & $61 \cdot 0$ & $68 \cdot 0$ & $59 \cdot 0$ & $4 \cdot 3$ & $4 \cdot 0$ & $4 \cdot 8$ & $4 \cdot 2$ \\
\hline Succinic & $125 \cdot 0$ & $96 \cdot 0$ & $122 \cdot 0$ & $115 \cdot 0$ & $2 \cdot 2$ & $2 \cdot 1$ & $2 \cdot 9$ & $2 \cdot 4$ \\
\hline Fumaric & $104 \cdot 0$ & $100 \cdot 0$ & $113 \cdot 0$ & $110 \cdot 0$ & $2 \cdot 1$ & $2 \cdot 0$ & $3 \cdot 2$ & $\mathbf{2 \cdot 5}$ \\
\hline L-Malic & $92 \cdot 0$ & $87 \cdot 0$ & $109 \cdot 0$ & $107 \cdot 0$ & $\mathbf{2 \cdot 0}$ & $1 \cdot 8$ & $\mathbf{3 \cdot 6}$ & $\mathbf{2 \cdot 0}$ \\
\hline Oxaloacetic + acetoacetic & $27 \cdot 0$ & $297 \cdot 0$ & $22 \cdot 0$ & $168 \cdot 0$ & $4 \cdot 5$ & $8 \cdot 4$ & $4 \cdot 6$ & $12 \cdot 0$ \\
\hline
\end{tabular}


Table 3. Average concentration and ${ }^{14} \mathrm{C}$-activity of Krebs-cycle acids in tissue homogenates incubated with $\left[1-{ }^{14} \mathrm{C}\right]$ acetate in the presence of triethyltin acetate

Values are net syntheses above controls and are averages of two experiments with different batches of pooled tissues. The compositions of the substrate and incubation mixture are given in Table 1, with the exception that triethyltin acetate at a final concentration of $1 \mu \mathrm{M}$ replaced $\mathrm{NaF}$ as an adenosine-triphosphatase inhibitor.

\begin{tabular}{|c|c|c|c|c|}
\hline \multirow[b]{2}{*}{ Acid } & \multicolumn{2}{|c|}{ Liver } & \multicolumn{2}{|c|}{ LC-18 carcinoma } \\
\hline & ( $\mu$ moles $/ 100$ g.) & $\begin{array}{c}\left(10^{-3} \times \text { Counts } /\right. \\
\text { min. } / 100 \mathrm{~g} .)\end{array}$ & ( $\mu$ moles $/ 100 \mathrm{~g})$. & $\begin{array}{c}\left(10^{-3} \times \text { Counts } /\right. \\
\text { min. } / 100 \text { g. })\end{array}$ \\
\hline Citric & $3 \cdot 2 \pm 0 \cdot 02$ & $112 \cdot 0$ & $0.7 \pm 0.02$ & $8 \cdot 1$ \\
\hline Aconitic (cis +trans) & $0.7 \pm 0.02$ & $\mathbf{3 3 \cdot 0}$ & $0.4 \pm 0.03$ & $\mathbf{3} \cdot \mathbf{1}$ \\
\hline isoCitric & $0 \cdot 6 \pm 0.03$ & $\mathbf{3 5 \cdot 0}$ & $0.5 \pm 0.03$ & $\mathbf{3} \cdot \mathbf{3}$ \\
\hline$\alpha$-Oxoglutaric & $4 \cdot 1 \pm 0.05$ & $100 \cdot 0$ & $1.8 \pm 0.04$ & $4 \cdot 0$ \\
\hline Succinic & $4.3 \pm 0.02$ & $122 \cdot 0$ & $2 \cdot 0 \pm 0.05$ & $\mathbf{3} \cdot 0$ \\
\hline Fumaric & $4 \cdot 0 \pm 0.06$ & $108 \cdot 0$ & $2 \cdot 3 \pm 0.04$ & $\mathbf{3} \cdot \mathbf{3}$ \\
\hline L-Malic & $3 \cdot 6 \pm 0 \cdot 05$ & $94 \cdot 0$ & $1 \cdot 3 \pm 0.07$ & $3 \cdot 8$ \\
\hline Oxaloacetic + acetoacetic & $1 \cdot 2 \pm 0 \cdot 03$ & $\mathbf{3 0} \cdot \mathbf{0}$ & $1 \cdot 4 \pm 0.03$ & $4 \cdot 9$ \\
\hline
\end{tabular}

Table 4. Cycle acids in ascites-tumour cells incubated with $\left[1-{ }^{14} \mathrm{C}\right]$ acetate $+20 \%$ of ascites fluid

Values are net syntheses above controls and are averages of three experiments, \pm average deviations, with different batches of pooled tissues. The compositions of the substrate and the incubation mixture are given in Table 1. Where used, $\mathbf{7 5 . 0} \mathrm{mg}$. of sodium malonate was added to the incubation mixture. No substrate was added to the controls. Blank values indicate amounts too small to be measured accurately.

\begin{tabular}{|c|c|c|c|c|c|c|c|}
\hline \multirow[b]{2}{*}{ Acid } & \multicolumn{4}{|c|}{$\mu$ moles $/ 100 \mathrm{~g}$. of packed cells } & \multicolumn{3}{|c|}{ of packed cells } \\
\hline & Control & Acetate & $\begin{array}{l}\text { Fluoro- } \\
\text { acetate } \\
\text { added }\end{array}$ & $\begin{array}{l}\text { Malonate } \\
\text { added }\end{array}$ & Acetate & $\begin{array}{l}\text { Fluoro- } \\
\text { acetate } \\
\text { added }\end{array}$ & $\begin{array}{l}\text { Malonate } \\
\text { added }\end{array}$ \\
\hline$s+\operatorname{trans})$ & - & $1.5 \pm 0.03$ & $2 \cdot 3 \pm 0.05$ & $2 \cdot 1 \pm 0.06$ & $\begin{array}{l}4 \cdot 3 \\
1 \cdot 4\end{array}$ & $\begin{array}{l}6 \cdot 4 \\
1.3\end{array}$ & $\begin{array}{l}6 \cdot 0 \\
1.6\end{array}$ \\
\hline$s+\operatorname{trans})$ & - & - & - & - & $\begin{array}{l}1.4 \\
1.4\end{array}$ & $\begin{array}{l}1 \cdot 3 \\
1 \cdot 2\end{array}$ & $\begin{array}{l}1 \cdot 0 \\
1 \cdot 6\end{array}$ \\
\hline c+acetoacetic & $\begin{array}{c}-\overline{0} \\
0.9 \pm 0.03 \\
0.7 \pm 0.02 \\
- \\
-\end{array}$ & $\begin{array}{l}1 \cdot 3 \pm 0.02 \\
2 \cdot 0 \pm 0.04 \\
1 \cdot 9 \pm 0.05 \\
1 \cdot 6 \pm 0.04 \\
2 \cdot 7 \pm 0.06\end{array}$ & $\begin{array}{l}1 \cdot 0 \pm 0.03 \\
1 \cdot 8 \pm 0.05 \\
1 \cdot 8 \pm 0.07 \\
1 \cdot 5 \pm 0.03 \\
3 \cdot 3 \pm 0.07\end{array}$ & $\begin{array}{l}1 \cdot 2 \pm 0.02 \\
2 \cdot 4 \pm 0.03 \\
1 \cdot 1 \pm 0.01 \\
1 \cdot 5 \pm 0.05 \\
2 \cdot 4 \pm 0.08\end{array}$ & $\begin{array}{l}3 \cdot 3 \\
5 \cdot 4 \\
5 \cdot 1 \\
4 \cdot 2 \\
7 \cdot 5\end{array}$ & $\begin{array}{l}2 \cdot 9 \\
5 \cdot 3 \\
4 \cdot 9 \\
3 \cdot 9 \\
9 \cdot 4\end{array}$ & $\begin{array}{l}3 \cdot 4 \\
6 \cdot 9 \\
4 \cdot 3 \\
3 \cdot 9 \\
6 \cdot 9\end{array}$ \\
\hline
\end{tabular}

The amounts of lactic acid and pyruvic acid in the different tissues were also determined together with the cycle acids in all experiments. The concentrations of these two acids were invariably greater in all tumour tissues studied than in the normal tissues. This observation is in agreement with that of other investigators (Olsen, 1951; Heidelberger, 1953; Warburg, 1956; Weinhouse et al. 1956).

Because the Walker and LC-18 tumours are a composite tissue and have a varying cancer-cell content, their use could, undoubtedly, lead to uncertainty in interpretation. It was thought advisable, therefore, to carry out further experiments on Ehrlich mouse-ascites-tumour cells, which are a nearly pure culture of intact cancer cells. Moreover, the utilization of unruptured ascites cells minimizes the uncertainty of ATP loss resulting from homogenization. At first, suspensions of these cells in Krebs-Ringer phosphate alone were used. The results of three experiments on different preparations of ascites cells indicated that acetate was incorporated into the various citric acid-cycle acids to a lesser degree than that in the normal tissues. Most of the substrate appeared to have been diverted mainly to the formation of acetoacetate and fatty acids. Indeed, a greater portion of the ${ }^{14} \mathrm{C}$-activity resided in the ether extract mentioned above. In further experiments, in order to provide more nearly physiological conditions for incubation, $20 \%$ of ascites fluid was incorporated into the incubation medium, replacing an equivalent amount of Krebs-Ringer phosphate. The use of ascites fluid in the incubation medium has been found advantageous by others (Kun, Talalay \& Williams-Ashman, 1951; Warburg, 1956). Indeed, in the present study, the inclusion of ascites fluid in the incubation mixture employed in this and the subsequent experiments increased the concentrations and activities of the citric acidcycle acids over those obtained with $\mathrm{Krebs}-\mathrm{Ringer}$ phosphate alone. As is evident from the data presented in Table 4, however, the activity of the cycle is less than that of the normal tissues studied (Tables 1 and 2). 
Since high concentrations of DPN have been reported to increase the oxygen uptake of hepatoma and liver mitochondria (Wenner \& Weinhouse, 1952), the effect of the two concentrations of this cofactor (2 or $5 \mathrm{mg}$.) on the utilization of acetate by the ascites-tumour cells was studied. In spite of the fact that the addition of DPN did not seem to raise the concentrations and activities of the Krebs-cycle intermediates to any appreciable extent, its inclusion in the incubation mixture, as stated earlier, was continued simply as a precautionary measure.

In addition to the effect of fluoroacetate upon the activity of the Krebs cycle, malonate, a specific inhibitor of succinic dehydrogenase (Pardee \& Potter, 1949), was also studied. Its use as a blocking agent should result in the accumulation of succinate. The results in Table 4 show that, although there was an accumulation of succinate, this was small. As with fluoroacetate inhibition, this observation points to a reduced activity of the cycle in these cells. This is not in complete disagreement with the experiments in vivo of other investigators (Busch \& Potter, 1952), who demonstrated that several tissues, including five tumours, accumulated succinate in the presence of malonate. Their data were interpreted to mean only that the Krebs cycle is functioning in these tissues, and do not point to the extent of the cycle activity. Despite this finding, however, these authors cautioned against drawing definite conclusions based on their data alone, since succinate may have arisen from sources other than the citric acid-cycle intermediates, e.g. glutamic acid.

The results given thus far strengthen the thesis that the citric acid cycle is operating at a lower level in the tumour tissues studied than in normal tissues. This could be due to a block(s) of an unknown nature either within or outside the cycle, hindering acetate from entering into the cycle. In order to obtain further evidence on the former point, two of the intermediates of the cycle itself were employed as substrates, in addition to acetate.

In one series, non-labelled L-malic acid mixed with labelled acetate was incubated with the tumour-cell suspension. In another, radioactive succinate mixed with non-labelled acetate was used. The results of these experiments are given in Tables 5 and 6 respectively. Again, the data clearly demonstrated that these two intermediates were not utilized by the cycle enzymes better than was acetate alone (Table 4). This was expected, at least with respect to succinate, since the succinicdehydrogenase activity in tumour tissue is believed to be low (Schneider \& Potter, 1943). Further, the occurrence of a weak electron-transport chain reported by Schneider \& Potter (1943) and others (Greenstein et al. 1944) could also be a contributing factor. The use of fluoroacetate and malonate as inhibitors, also, did not significantly alter the concentrations of citrate or succinate respectively. This finding is similar to that obtained above when acetate alone was used as a substrate (Table 4). If there were an impairment in the pathway between acetate and citrate, one of two possibilities, or both, could be a contributing factor(s). Either the activating-enzyme system of acetate which brings about the formation of acetyl-CoA or the condensing enzyme might not be functioning normally. Other studies, however, appear to rule out the latter possibility (Wenner et al. 1952). This leaves the former as a possible alternative mechanism. One could speculate, therefore, that acetyl-CoA may not have been biosynthesized in sufficient quantities or that its production was at such a slow rate that it could not keep pace with the turnover by the condensing enzyme. To explore this point, the systems of the experiments that follow were fortified with $5 \mathrm{mg}$. of $\mathrm{CoA}$ to test its effect on the utilization of acetate or succinate by

Table 5. Cycle acids in ascites-tumour cells incubated with substrate containing $1.5 \mathrm{mg}$. of $\mathrm{L}$-malic acid

Values are net syntheses above controls and are averages of three experiments, \pm average deviations, with different preparations of ascites cells. The compositions of the substrate and incubation mixture are given in Tables 1 and 4. Blank values indicate amounts too small to be measured accurately.

\begin{tabular}{|c|c|c|c|c|c|c|c|}
\hline \multirow[b]{2}{*}{ Acid } & \multicolumn{4}{|c|}{$\mu$ moles $/ 100 \mathrm{~g}$. of packed cells } & \multicolumn{3}{|c|}{$\begin{array}{c}10^{-3} \times \text { Counts } / \mathrm{min} . / 100 \mathrm{~g} . \\
\text { of packed cells }\end{array}$} \\
\hline & Control & $\begin{array}{c}\text { Acetate }+ \\
\text { malate }\end{array}$ & $\begin{array}{c}\text { Fluoro- } \\
\text { acetate } \\
\text { added }\end{array}$ & $\begin{array}{l}\text { Malonate } \\
\text { added }\end{array}$ & $\begin{array}{c}\text { Acetate }+ \\
\text { malate }\end{array}$ & $\begin{array}{l}\text { Fluoro- } \\
\text { acetate } \\
\text { added }\end{array}$ & $\begin{array}{l}\text { Malonate } \\
\text { added }\end{array}$ \\
\hline tric & - & $1.4 \pm 0.02$ & $2 \cdot 3 \pm 0 \cdot 07$ & $2 \cdot 3 \pm 0 \cdot 07$ & $4 \cdot 5$ & 6.5 & $6 \cdot 1$ \\
\hline conitic (cis +trans) & - & 二 & - & - & $1 \cdot 3$ & $1 \cdot 3$ & $1 \cdot 4$ \\
\hline$o$ Citric & - & - & - & - & $1 \cdot 4$ & $1 \cdot 2$ & $1 \cdot 4$ \\
\hline Oxoglutaric & - & $1 \cdot 3 \pm 0.03$ & $1 \cdot 2 \pm 0 \cdot 08$ & $1 \cdot 5 \pm 0.04$ & $3 \cdot 4$ & $3 \cdot 2$ & $\mathbf{3} \cdot \mathbf{3}$ \\
\hline uccinic & $0.8 \pm 0.03$ & $2 \cdot 3 \pm 0.04$ & $2 \cdot 0 \pm 0 \cdot 1$ & $2.5 \pm 0.08$ & $5 \cdot 3$ & $5 \cdot 3$ & $6 \cdot 3$ \\
\hline imaric & $0.7 \pm 0.02$ & $2 \cdot 2 \pm 0.05$ & $1.9 \pm 0.04$ & $1 \cdot 7 \pm 0.09$ & $5 \cdot 0$ & 4.9 & $4 \cdot 4$ \\
\hline Malic & - & $1.9 \pm 0.04$ & $1 \cdot 7 \pm 0.05$ & $2 \cdot 0 \pm 0.06$ & 4.5 & $4 \cdot 1$ & $4 \cdot 1$ \\
\hline Oxaloacetic + acetoacetic & 一 & $3.0 \pm 0.08$ & $3.4 \pm 0.06$ & $3 \cdot 3 \pm 0.06$ & $7 \cdot 8$ & $9 \cdot \overline{7}$ & $6 \cdot 9$ \\
\hline
\end{tabular}


Table 6. Cycle acids in ascites-tumour cells incubated with $\left[1-{ }^{14} \mathrm{C}\right]$ succinic acid

Values are net syntheses above controls and are averages of two experiments, 士average deviations, with different preparations of ascites cells. The substrate contained: succinic acid, 5.0 mg.; [1-14C]succinic acid, $1.5 \mathrm{mg}$. (activity $1.3 \mathrm{mc} / \mathrm{m}$-mole); sodium acetate trihydrate, $2.0 \mathrm{mg}$.; in $50 \mathrm{ml}$. of Krebs-Ringer phosphate. The composition of the incubation mixture is given in Table 1. Blank values indicate amounts too small to be measured accurately. The high counts for succinic acid are due primarily to non-utilized [1-14 $\mathrm{C}] \mathrm{succinic}$ acid.

\begin{tabular}{|c|c|c|c|c|c|}
\hline \multirow[b]{2}{*}{ Acid } & \multicolumn{3}{|c|}{$\mu$ moles $/ 100 \mathrm{~g}$. of packed cells } & \multicolumn{2}{|c|}{$\begin{array}{c}10^{-8} \times \text { Counts } / \mathrm{min} . / 100 \mathrm{~g} \\
\text { of packed cells }\end{array}$} \\
\hline & Control & Succinate & $\begin{array}{l}\text { Succinate }+ \\
\text { fluoroacetate }\end{array}$ & Succinate & $\begin{array}{l}\text { Succinate }+ \\
\text { fluoroacetate }\end{array}$ \\
\hline $\begin{array}{l}\text { Citric } \\
\text { Aconitic (cis +trans) } \\
\text { isoCitric } \\
\alpha \text {-Oxoglutaric } \\
\text { Succinic } \\
\text { Fumaric } \\
\text { L-Malic } \\
\text { Oxaloacetic + acetoacetic }\end{array}$ & $\begin{array}{c}\bar{Z} \\
\bar{Z} \\
0.9 \pm 0 \cdot 02 \\
0 \cdot 8 \pm 0 \cdot 02 \\
=\end{array}$ & $\begin{array}{r}1 \cdot 3 \pm 0.03 \\
= \\
0 \cdot 8 \pm 0 \cdot 01 \\
20 \cdot 8 \pm 0 \cdot 08 \\
1 \cdot 7 \pm 0.04 \\
1 \cdot 6 \pm 0.07 \\
1 \cdot 1 \pm 0.03\end{array}$ & $\begin{array}{c}1 \cdot 4 \pm 0.02 \\
- \\
0.7 \pm 0.03 \\
21 \cdot 0 \pm 0.04 \\
1 \cdot 6 \pm 0.06 \\
1 \cdot 7 \pm 0.05 \\
1 \cdot 2 \pm 0.06\end{array}$ & $\begin{array}{r}11 \cdot 5 \\
5 \cdot 8 \\
5 \cdot 3 \\
7 \cdot 5 \\
361 \cdot 5 \\
18 \cdot 8 \\
17 \cdot 4 \\
14 \cdot 0\end{array}$ & $\begin{array}{r}12 \cdot 0 \\
4 \cdot 7 \\
4 \cdot 0 \\
7 \cdot 8 \\
395 \cdot 0 \\
18 \cdot 0 \\
16 \cdot 8 \\
14 \cdot 5\end{array}$ \\
\hline
\end{tabular}

Table 7. Cycle acids in ascites-tumour cells incubated with substrate containing acetyl-coenzyme $A$

Values are net syntheses above controls and are from one experiment. The compositions of the substrate and incubation mixture are given in Table 1 , with the exception that $2 \mu$ moles of acetyl-CoA were added. No substrate was added to the controls. Blank values indicate amounts too small to be measured accurately.

\section{Acid}

Citric

Aconitic (cis +trans)

isoCitric

$\alpha$-Oxoglutaric

Succinic

Fumaric

L-Malic

Oxaloacetic + acetoacetic

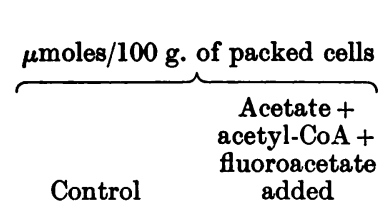

-

二

-

0.7

-

$10^{-8} \times$ Counts/
min./100 g. of
packed cells.
Acetate +
acetyl-CoA +
fluoroacetate
added
$6 \cdot 4$
$1 \cdot 3$
$1 \cdot 2$
$2 \cdot 9$
$5 \cdot 3$
$4 \cdot 9$
$3 \cdot 9$
$9 \cdot 3$

way of the citric acid cycle in ascites cells. If $\mathrm{CoA}$ is lacking or not present in adequate amounts, its addition to the incubation medium would be expected to raise the concentrations of the cycle members, provided that the other cofactors and the activating enzyme are not only present but are also functioning normally. It is assumed, of course, that this would be the case if the cycle itself is also operating at a normal level. When it was found that CoA failed to increase the concentrations of the cycle acids significantly under the experimental conditions, a further investigation with preformed acetyl-CoA was pursued (Table 7) in an effort to determine whether or not the activating system itself might be defective. Contrary to expectation, no increase in citrate in the presence of fluoroacetate was observed (cf. Table 4), a finding that can be considered as indirect evidence against an impairment of the acetate-activating system. The only increase under these conditions was in the oxaloacetate-acetoacetate fraction. This observation will be discussed later.

To assess still further the operation of the citric acid cycle in ascites-tumour cells, the activity of the cycle was compared under identical conditions with that in isolated liver cells and in nucleated erythrocytes (also suspensions of intact cells). The data (Table 8) show that the quantities and activities of the cycle members biosynthesized in hepatic cells and in nucleated erythrocytes are several times greater than those found in ascites-tumour cells. Particularly striking is the accumulation of citrate in nucleated erythrocytes when fluoroacetate is added. Likewise, when malonate is added to hepatic cells, there is a marked accumulation of succinate. 
Table 8. Comparison of cycle acids in ascites-tumour cells, isolated hepatic cells and nucleated erythrocytes incubated with the same substrate

Values are net syntheses above controls and are averages of three experiments, \pm average deviations, with different preparations of pooled cells. The compositions of the substrate and incubation mixture are given in Tables 1 and 4. Blank values indicate amounts too small to be measured accurately. The values for nucleated erythrocytes are taken from Dajani \& Orten (1958).

\begin{tabular}{|c|c|c|c|c|c|c|}
\hline \multirow[b]{2}{*}{ Acid } & \multicolumn{3}{|c|}{$\mu$ moles $/ 100 \mathrm{~g}$. of packed cells } & \multicolumn{3}{|c|}{$10^{-3} \times$ counts $/ \mathrm{min} . / 100 \mathrm{~g}$. of packed cells } \\
\hline & Acetate & $\begin{array}{l}\text { Fluoroacetate } \\
\text { added }\end{array}$ & $\begin{array}{l}\text { Malonate } \\
\text { added }\end{array}$ & Acetate & $\begin{array}{l}\text { Fluoroacetate } \\
\text { added }\end{array}$ & $\begin{array}{l}\text { Malonate } \\
\text { added }\end{array}$ \\
\hline \multicolumn{7}{|c|}{ Ascites cells } \\
\hline $\begin{array}{l}\text { Citric } \\
\text { Aconitic (cis +trans) } \\
\text { isoCitric } \\
\alpha \text {-Oxog!utaric } \\
\text { Succinic } \\
\text { Fumaric } \\
\text { L-Malic } \\
\text { Oxaloacetic + acetoacetic }\end{array}$ & $\begin{array}{l}1 \cdot 5 \pm 0.03 \\
= \\
1 \cdot 3 \pm 0 \cdot 02 \\
2 \cdot 0 \pm 0 \cdot 04 \\
1 \cdot 9 \pm 0 \cdot 05 \\
1 \cdot 6 \pm 0 \cdot 04 \\
2 \cdot 7 \pm 0.06\end{array}$ & $\begin{array}{l}2 \cdot 3 \pm 0.05 \\
= \\
1 \cdot 0 \pm 0.03 \\
1 \cdot 8 \pm 0.05 \\
1 \cdot 8 \pm 0.07 \\
1 \cdot 5 \pm 0.03 \\
3 \cdot 3 \pm 0.07\end{array}$ & $\begin{array}{l}2 \cdot 1 \pm 0 \cdot 06 \\
= \\
1 \cdot 2 \pm 0 \cdot 02 \\
2 \cdot 4 \pm 0 \cdot 03 \\
1 \cdot 1 \pm 0 \cdot 01 \\
1 \cdot 5 \pm 0 \cdot 05 \\
2 \cdot 4 \pm 0 \cdot 08\end{array}$ & $\begin{array}{l}4 \cdot 3 \\
1 \cdot 4 \\
1 \cdot 4 \\
3 \cdot 3 \\
5 \cdot 4 \\
5 \cdot 1 \\
4 \cdot 2 \\
7 \cdot 5\end{array}$ & $\begin{array}{l}6 \cdot 4 \\
1 \cdot 3 \\
1 \cdot 2 \\
2 \cdot 9 \\
5 \cdot 3 \\
4 \cdot 9 \\
3 \cdot 9 \\
9 \cdot 4\end{array}$ & $\begin{array}{l}6 \cdot 0 \\
1 \cdot 6 \\
1 \cdot 6 \\
3 \cdot 4 \\
6 \cdot 9 \\
4 \cdot 3 \\
3 \cdot 9 \\
6 \cdot 9\end{array}$ \\
\hline \multicolumn{7}{|c|}{ Isolated hepatic cells } \\
\hline $\begin{array}{l}\text { Citric } \\
\text { Aconitic (cis }+ \text { trans) } \\
\text { isoCitric } \\
\alpha \text {-Oxoglutaric } \\
\text { Succinic } \\
\text { Fumaric } \\
\text { L-Malic } \\
\text { Oxaloacetic + acetoacetic }\end{array}$ & $\begin{array}{l}3 \cdot 0 \pm 0 \cdot 02 \\
0 \cdot 7 \pm 0 \cdot 01 \\
0 \cdot 8 \pm 0 \cdot 02 \\
4 \cdot 2 \pm 0 \cdot 04 \\
4 \cdot 3 \pm 0 \cdot 03 \\
3 \cdot 8 \pm 0 \cdot 06 \\
3 \cdot 3 \pm 0 \cdot 06 \\
1 \cdot 2 \pm 0 \cdot 02\end{array}$ & $\begin{array}{l}1 \cdot 9 \pm 0 \cdot 03 \\
0 \cdot 6 \pm 0 \cdot 04 \\
0 \cdot 5 \pm 0 \cdot 02 \\
2 \cdot 6 \pm 0 \cdot 03 \\
3 \cdot 9 \pm 0 \cdot 05 \\
3 \cdot 6 \pm 0 \cdot 06 \\
3 \cdot 2 \pm 0 \cdot 04 \\
5 \cdot 8 \pm 0.05\end{array}$ & $\begin{array}{l}1 \cdot 9 \pm 0 \cdot 05 \\
0 \cdot 6 \pm 0 \cdot 04 \\
0 \cdot 5 \pm 0 \cdot 02 \\
4 \cdot 5 \pm 0 \cdot 05 \\
6 \cdot 7 \pm 0 \cdot 06 \\
2 \cdot 1 \pm 0 \cdot 03 \\
2 \cdot 2 \pm 0 \cdot 04 \\
3 \cdot 5 \pm 0.07\end{array}$ & $\begin{array}{r}113 \cdot 0 \\
30 \cdot 5 \\
38 \cdot 0 \\
97 \cdot 0 \\
128 \cdot 0 \\
107 \cdot 0 \\
93 \cdot 0 \\
29 \cdot 0\end{array}$ & $\begin{array}{r}112 \cdot 0 \\
29 \cdot 5 \\
34 \cdot 0 \\
63 \cdot 0 \\
99 \cdot 0 \\
101 \cdot 0 \\
88 \cdot 0 \\
212 \cdot 0\end{array}$ & $\begin{array}{r}110 \cdot 5 \\
32 \cdot 5 \\
35 \cdot 0 \\
102 \cdot 0 \\
165 \cdot 5 \\
75 \cdot 8 \\
66 \cdot 0 \\
97 \cdot 0\end{array}$ \\
\hline \multicolumn{7}{|c|}{ Nucleated erythrocytes } \\
\hline $\begin{array}{l}\text { Citric } \\
\text { Aconitic (cis +trans) } \\
\text { isoCitric } \\
\alpha \text {-Oxoglutaric } \\
\text { Succinic } \\
\text { Fumaric } \\
\text { L-Malic } \\
\text { Oxaloacetic + acetoacetic }\end{array}$ & $\begin{array}{r}28 \cdot 5 \\
1 \cdot 6 \\
1 \cdot 6 \\
16 \cdot 0 \\
49 \cdot 7 \\
51 \cdot 0 \\
39 \cdot 5 \\
28 \cdot 0\end{array}$ & $\begin{array}{r}49 \cdot 5 \\
1 \cdot 1 \\
1 \cdot 1 \\
3 \cdot 6 \\
48 \cdot 5 \\
49 \cdot 5 \\
39 \cdot 0 \\
135 \cdot 0\end{array}$ & & $\begin{array}{r}1380 \cdot 0 \\
67 \cdot 2 \\
68 \cdot 8 \\
432 \cdot 0 \\
1650 \cdot 0 \\
1440 \cdot 0 \\
1220 \cdot 0 \\
785 \cdot 0\end{array}$ & $\begin{array}{r}2310 \cdot 0 \\
48 \cdot 5 \\
47 \cdot 9 \\
95 \cdot 5 \\
1740 \cdot 0 \\
1390 \cdot 0 \\
1080 \cdot 0 \\
3780 \cdot 0\end{array}$ & \\
\hline
\end{tabular}

\section{DISCUSSION}

It appears from work in other laboratories (see references cited in introduction), with manometric, enzymic and isotopic techniques, that segments of the citric acid cycle proceed, to some extent at least, in tumour tissue. On the other hand, there is also evidence which indicates that the activity of the cycle is of a lower order than that of many normal tissues. The results presented in the present paper, however, indicate clearly that the activity of the citric acid cycle in the tumour tissues studied is of a lower order than that in the normal control tissues. This is based on the interpretation that the concentrations and total ${ }^{14} \mathrm{C}$-activities of the intermediates in the cycle reflect the amount of material passing through it. Another possible interpretation, on the other hand, is that the lower concentrations of the acids in the tumour tissues could mean that the cycle is as active or even more active in these tissues, provided that the enzyme levels are higher. However, measurement of the levels of certain enzymes of the citric acid cycle and some other related enzymes, have shown that they are either comparable or lower, but never higher, in tumour tissues. The enzymes measured include cytochrome oxidase (Greenstein et al. 1944), succinic dehydrogenase and cytochrome oxidase (Schneider \& Potter, 1943), aconitase (Weinhouse, 1951), malic dehydrogenase (Potter, 1946), condensing enzyme (Potter \& Busch, 1950), and lactic, $\alpha$-oxoglutaric, malic and isocitric dehydrogenases, fumarase, oxaloacetic carboxylase, condensing enzyme and aconitase (Wenner et al. 1952). Further, an equal or higher activity of the cycle in tumour tissues would require a higher rate of acetate utilization when acetate was used as the substrate. Actually, acetate utilization has been found by several investigators to be much less in tumour than in the normal tissues that they have studied. Pardee, Heidelberger \& Potter (1950) measured the oxidation of $\left[1-{ }^{14} \mathrm{C}\right]$ acetate to ${ }^{14} \mathrm{CO}_{2}$ in slices and homogenates of tumour and nontumour tissues and found that less than one- 
twenty-fifth as much ${ }^{14} \mathrm{CO}_{2}$ was produced by tumour as by kidney. Similar results were later obtained by Busch \& Baltrush (1954). Another line of evidence for the occurrence of a reduced activity of the Krebs cycle was provided by Kit \& Greenberg (1951), who were able to show that acetate was oxidized to carbon dioxide in Gardner lymphosarcoma to about one-third the extent of that in spleen, one of the normal tissues of relatively low oxidizing activity. Also, citrate accumulation was almost of the same magnitude in the presence of fluoroacetate as in its absence. Weinhouse (1951), on the other hand, has shown that ${ }^{14} \mathrm{CO}_{2}$ is formed in approximately equal quantities from various substrates, including acetate, by tumour and normal-tissue slices. Further, when $\left[2-{ }^{14} \mathrm{C}\right]$ pyruvate is used as a substrate, ${ }^{14} \mathrm{CO}_{2}$ production in hepatoma was nearly the same as that produced in liver (Olson, 1951). Thus most of the observations in vitro cited above indicate a lower activity of the cycle in the tumour tissues studied, as was found by a different procedure in the present study.

Further evidence of a diminished activity of segments of the citric acid cycle have been furnished by several experiments in vivo. Potter \& Busch (1950) determined the citric acid content of tissues of fluoroacetate-treated rats and found it to accumulate in most tissues with the exception of liver, testis and tumour. The inability of the liver, which is known to exhibit high citric acid-cycle activity, to accumulate citrate was explained on the basis of the occurrence of another pathway for acetate and pyruvate utilization, namely acetoacetate formation. The absence of citrate accumulation in tumour was considered as 'strong evidence that the ability of tumour tissues to form citrate is very low in comparison with a wide variety of normal tissues'. Other experiments on transplanted rat tumour in vivo also showed either no significant acetate or pyruvate oxidation (Busch \& Baltrush, 1954; Busch, 1955), or, with the uptake of glutamate or succinate, activity of only a portion of the citric acid cycle (Nyhan \& Busch, 1958).

Recently Busch, Davis \& Olle (1957) have demonstrated that only 'under optimal conditions (i.e. excess of a variety of substrates of the citric acid cycle, pH 7.4, and an atmosphere of 100 per cent oxygen) is the capacity of transplantable rat tumour for production of citrate essentially the same as that of a variety of non-tumour tissues'. Even under such unphysiological conditions as these, their data show that citrate accumulation was significantly greater in the normal tissues than in any of the tumours investigated.

The present study provides a more complete and direct demonstration of a low activity of the entire
Krebs cycle in certain tumours. It is evident that, with the exception of the oxaloacetate fraction, which contains an appreciable quantity of acetoacetate, the amounts and activities (Tables 1 and 2) of all the cycle intermediates in liver or muscle were always greater than in the two tumour tissues. The experiments with fluoroacetate furnished further support for this observation. The apparent increase in the oxaloacetate fraction would be expected from the effect of fluoroacetate inhibition of the citric acid cycle and the diversion of a considerable portion of acetate towards fatty acid biosynthesis (Crandall, Gurin \& Wilson, 1947).

The studies of Ehrlich ascites cells gave even more convincing evidence about the status of the cycle in tumours. Here again, the quantities and activities of the cycle acids (Table 4) are decidedly less than those in isolated liver cells or nucleated erythrocytes (Table 8). Further, the values are less than those for liver or muscle (Tables 1 and 2). These differences are also apparent if specific activities, which reflect rate of turnover and hence the extent of the activity of the cycle enzymes, are calculated and then compared. Indeed, the specific activities of the individual intermediates in tumours are definitely much less than their counterparts in the normal tissues.

Although the foregoing observations tend to support the view that the Krebs cycle is of low activity in tumours, they have left undecided the question of whether or not a block(s) exists outside the cycle which could hinder the normal entrance of acetate into it. One could assume either an enzyme or a cofactor, or both, to be the limiting factor(s). As a matter of fact, several cofactors, such as DPN, ATP and CoA, are known to be involved in these reactions and would retard the rate of citrate biosynthesis if they were not present in sufficient quantities. Also, two enzyme systems are recognized as being concerned with the reactions that lead to citrate formation from acetate, namely the activating and condensing enzymes. The latter, however, is not believed to exist in tumours in levels comparable with those in non-tumours (Wenner et al. 1952). Because DPN and ATP were used in all experiments, including the control, only the CoA was tested for its effect on the utilization of acetate or succinate by way of the citric acid cycle in the ascites cells. The present results make it clear that the cycle components did not increase any more in the presence of CoA than in its absence. This would suggest that CoA either does not penetrate the cell readily or that tumours are less able to activate acetate than many normal tissues. Although no attempt was made to investigate the permeability of the ascites cell to CoA in the present investigation, the formation of acetylCoA was studied by indirect means. If acetate 
were not normally metabolized via the citric acid cycle because of a lack or a subnormal activity of the activating enzyme, it would be reasonable to assume that adding preformed acetyl-CoA would increase the output of citrate in the presence of fluoroacetate. Acetyl-CoA did not produce any such increase in the citrate concentration (Table 8). It is, of course, possible that acetyl-CoA may also not have penetrated the cell or that it may have been deacylated. The simplest explanation of the inactivity of acetyl-CoA is, of course, that it does not penetrate the cell. However, if it be assumed that permeability and deacylation are not in fact important factors, then these results suggest that there is no deficiency of activating-enzyme activity in ascites-tumour cells and perhaps in other types of tumours. This is supported by the observation that there was a marked increase in the production of acetoacetate and fatty acids; such a finding argues against an impairment in the activatingenzyme system, since acetyl-CoA formation is established to be the first step in the biosynthesis of these substances. This finding would also argue against any possible excessive destruction of ATP and DPN, which, of course, could retard the cycle activity in the tumour tissues employed.

In view of the present findings, together with those in the literature cited, it seems reasonable to conclude that the reactions of the Krebs cycle are of a lower order in the tumour as compared with normal tissues investigated. A diminished amount or activity, or both, of some intracycle enzyme system(s) appears to be the limiting factor.

\section{SUMMARY}

1. The operation of the Krebs cycle in certain tumour and non-tumour tissues has been studied by measuring the concentrations and ${ }^{14} \mathrm{C}$-activities of the cycle intermediates when acetate, malate and/or succinate were used as substrates in the presence and absence of the blocking agents, fluoroacetate and malonate. The utilization of these substances by way of the citric acid cycle was less in the Walker, LC-18 and mouse ascites tumours than in muscle, liver (homogenates and isolated intact cells) or nucleated erythrocytes.

2. Addition of adenosine triphosphate and two concentrations of diphosphopyridine nucleotide to the incubation mixture, in the presence of fluoride or triethyltin acetate, did not result in any appreciable increase in the amounts or ${ }^{14} \mathrm{C}$-activities of the citric acid-cycle members in tumours. Likewise, fortifying the incubation mixture with either coenzyme $\mathbf{A}$ or preformed acetyl-coenzyme A failed to produce a significant increase in the quantities and activities of the cycle acids. The only increase was in the lipid and acetoacetate fractions. This was considered to indicate that there was no apparent impairment in the activatingenzyme system or excessive loss of adenosine triphosphate or diphosphopyridine nucleotide in the tumours employed.

3. The cycle intermediates, succinate and malate, were not utilized any better by the tumour tissues than was acetate.

4. In view of the above findings, it is concluded that the lower activity of the cycle in the tumour than in the normal tissues studied is primarily due to some defect in an intra-Krebs-cycle reaction(s).

The authors wish to express their deep gratitude to the staff of the Detroit Cancer Research Institute for their generosity in supplying all the tumour-bearing animals employed in this study. Grateful thanks are also due to our colleague, Dr J. J. Jasper, for a very pure sample of fluoroacetic acid. We are especially indebted to Dr D. E. Green, of the University of Wisconsin, for supplying acetyl-CoA, a material which has added more weight to the findings of this investigation. This work was supported by Research Grant no. CY-2144 from the National Institutes of Health.

\section{REFERENCES}

Beck, W. S. (1958). J. biol. Chem. $232,251$.

Branster, V. M. \& Morton, R. K. (1957). Nature, Lond., 180, 1283.

Busch, H. (1955). Cancer Res. 15, 365.

Busch, H. \& Baltrush, H. A. (1954). Cancer. Res. 14, 448.

Busch, H., Davis, J. R. \& Olle, E. W. (1957). Cancer Res. 17, 711 .

Busch, H. \& Potter, V. R. (1952). Cancer Res. 12, 660.

Cori, C. F. \& Cori, G. T. (1925). J. biol. Chem. 65, 397.

Crandall, D. I., Gurin, S. \& Wilson, D. W. (1947). Fed. Proc. 6, 246.

Dajani, R. M. \& Orten, J. M. (1958). J. biol. Chem. 231, 913.

Dubois, K. P. \& Potter, V. R. (1942). Cancer Res. 2, 290.

Elliott, W. B. \& Kalnitsky, G. (1950). J. biol. Chem. 186, 487.

Greenstein, J. P., Werne, J., Eschenbrenner, A. B. \& Leuthardt, F. M. (1944). J. nat. Cancer Inst. 5, 55.

Heidelberger, C. (1953). Advanc. Cancer Res. 1, 273.

Ibsen, K. H., Coe, E. L. \& McKee, R. W. (1958). Biochim. biophys. Acta, 30, 384.

Kit, S. \& Greenberg, D. M. (1951). Cancer Res. 11, 495.

Kun, E., Talalay, P. \& Williams-Ashman, H. G. (1951). Cancer Res. 11, 855.

LePage, G. A. (1950). Cancer Res. 10, 77.

Meister, A. (1950). J. nat. Cancer Inst. 10, 1263.

Nyhan, W. L. \& Busch, H. (1958). Cancer Res. 18, 385, 1203.

Olsen, R. E. (1951). Cancer Res. 11, 571.

Pardee, A. B., Heidelberger, C. \& Potter, V. R. (1950). J. biol. Chem. 186, 625.

Pardee, A. B. \& Potter, V. R. (1949). J. biol. Chem. 178, 241.

Potter, V. R. (1946). J. biol. Chem. 165, 311.

Potter, V. R. (1951). Cancer Res. 11, 565. 
Potter, V. R. \& Busch, H. (1950). Cancer Res. 10, 353.

Schneider, W. C. \& Potter, V. R. (1943). Cancer Res. 3, 353.

Sibley, J. A. \& Lehninger, A. L. (1949). J. nat. Cancer Inst. 9, 303.

Warburg, O. (1926). Uber den Stoffwechsel der Tumoren. Berlin: Julius Springer

Warburg, O. (1956). Science, 123, 309.
Weinhouse, S. (1951). Cancer Res. 11, 585.

Weinhouse, S. (1955). Advanc. Cancer Res. 3, 269.

Weinhouse, S., Warburg, O. \& Burk, D. (1956). Science, 124, 267.

Wenner, C. E., Spirtes, M. A. \& Weinhouse, S. (1952). Cancer Res. 12, 44.

Wenner, C. E. \& Weinhouse, S. (1952). Cancer Res. 12, 306.

Wenner, C. E. \& Weinhouse, S. (1953). Cancer Res. 13, 21.

Biochem. J. (1961) 81, 503

\title{
The Metabolism of $\mathrm{G}_{2}$-Compounds in Micro-organisms
}

\section{A DICARBOXYLIC ACID CYCLE AS A ROUTE FOR THE OXIDATION OF GLYCOLLATE BY ESCHERICHIA COLI*}

\author{
BY H. L. KORNBERG $\dagger$ AND J. R. SADLER $\ddagger$ \\ Medical Research Council Cell Metabolism Research Unit, Department of Biochemistry, \\ University of Oxford
}

(Received 25 May 1961)

Although the tricarboxylic acid cycle has been established as the major route for the oxidation of acetate, and of compounds catabolized to acetate, in a wide variety of organisms (for review, see Krebs \& Lowenstein, 1960) little is known of the pathways of oxidation of $\mathrm{C}_{2}$ compounds more highly oxidized than acetate, such as glycollate or glyoxylate. The main purpose of this paper is to show that, whereas the tricarboxylic acid cycle plays an essential role in the growth of Escherichia coli on glycollate as sole carbon source, this cycle is not necessary for glycollate oxidation. The results obtained with the mutant M 22-64 of $E$. coli, strain $w$, which is devoid of the citrate-forming condensing enzyme (Gilvarg \& Davis, 1957), and with its parent wild type, support the view that glyoxylate, derived from the oxidation of glycollate, can be oxidized completely via a dicarboxylic acid cycle in which glyoxylate condenses with acetylcoenzyme A to form malate, which is oxidized via oxaloacetate and pyruvate to regenerate the acetyl-coenzyme A required for the initial condensation. An outline of this work has been published (Kornberg \& Sadler, 1960).

\section{MATERIALS AND METHODS}

Maintenance and growth of micro-organisms. The microorganisms used in this work were $E$. coli, strain $w$, and the mutant M 22-64 isolated and characterized by Gilvarg \& Davis (1957). The mutant differed from its parent wild

\footnotetext{
* Part 7: Gotto \& Kornberg (1961).

$\dagger$ Present address: Department of Biochemistry, University of Leicester.

$\ddagger$ Present address: Institute of Molecular Biology, University of Oregon (U.S.A.).
}

strain in being unable to catalyse the condensation of acetyl-coenzyme $A$ and oxaloacetate to form citrate, and hence required the addition of glutamate for growth. The original cultures of the mutant and of the parent wild type were gifts from Professor B. D. Davis (Harvard Medical School, Boston, Mass., U.S.A.).

Cultures of the mutant and of the parent wild type were grown and maintained on agar slopes, containing $50 \mathrm{~mm}$ -

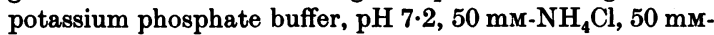
sodium glycollate, $2 \mathrm{~mm}$-sodium glutamate and essential salts (4 mg. of $\mathrm{CaCl}_{2}, 6 \mathrm{H}_{2} \mathrm{O} ; 0 \cdot 2 \mathrm{mg}$. of $\mathrm{MnCl}_{2}, 4 \mathrm{H}_{2} \mathrm{O} ; 4 \mathrm{mg}$. of $\mathrm{MgSO}_{4}, 7 \mathrm{H}_{2} \mathrm{O}$ and $0.2 \mathrm{mg}$. of $\mathrm{FeSO}_{4}, 6 \mathrm{H}_{2} \mathrm{O}$ per $100 \mathrm{ml}$. of medium) solidified with $1.5 \%(w / v)$ of agar agar (Hopkin and Williams Ltd., Chadwell Heath, Essex). Stock cultures of the organism were subcultured every 2 weeks, grown at $30^{\circ}$ and stored at $2^{\circ}$.

For growth in liquid medium, a loopful of organisms from a freshly grown slope was suspended in $400 \mathrm{ml}$. of the above medium with the agar omitted (hereafter referred to as 'glycollate-glutamate' medium) in a Carrel culture flask (J. A. Jobling and Co. Ltd., Sunderland). The flasks were shaken for 30-35 hr. on a reciprocal shaker at $30^{\circ}$. Growth of the cells was determined by measurements in an EEL Unigalvo Type 20 nephelometer (Evans Electroselenium Ltd., Harlow, Essex) of the light-scattering of samples of the bacterial suspensions and comparison of the observed readings with a previously constructed calibration curve relating such readings to the dry weight of bacteria $/ \mathrm{ml}$. of suspension. Although the medium was shown to be adequate to sustain the growth of more than $1 \mathrm{mg}$. dry wt. of bacteria $/ \mathrm{ml}$., the organisms were harvested while in the phase of logarithmic growth, at densities of $0.2-0.5 \mathrm{mg}$. dry wt./ml. The contents of the Carrel culture flasks were centrifuged at $10^{\circ}$ for $15 \mathrm{~min}$. at $1500 \mathrm{~g}$.

Oxidation studies. The packed cells were suspended in $100-150 \mathrm{ml}$. of potassium phosphate, $\mathrm{pH} 7 \cdot 2$, centrifuged at $1500 \mathrm{~g}$ for $10 \mathrm{~min}$., and resuspended in a sufficient volume of buffer to give a cell density of $5 \mathrm{mg}$. dry wt. $/ \mathrm{ml}$. Samples (2 ml.) of this washed cell suspension were pipetted into the main compartment of Warburg manometer cups. 